\title{
LINK BETWEEN BOARD STRUCTURE AND NATIONAL CULTURE: A COMPARATIVE ANALYSIS
}

As a result of the separation of ownership from control and relationship between the owners as principals and managers as agents, the so-called agency problem arises. In order to alleviate the agency problem in transition economies, internal corporate governance mechanisms are applied. Culture is considered as one of the most important factors within an informal institutional framework that is often associated with the effectiveness of corporate governance mechanisms. Starting from the fact that the board is an important internal mechanism, this paper examines the national culture as a determinant of the board structure based on a widely accepted cultural framework developed by Geert Hofstede. The aim of the research is to obtain relevant scientific knowledge on whether the board structure, analyzed through board composition and size, differs in countries that have similar dimensions of national culture. The research is carried out on a sample of 60 companies in Serbia and Montenegro. Relying on the T-test, the reserch showed that the boards composition in these countries differs, while their average size is the same. This pilot study mitigates the research gap that exists in domestic literature and represents the basis for future research in this area.

Keywords: corporate governance, corporate governance mechanisms, national culture, board structure

Faculty of Economics, Universtity of Kragujevac; jnikolic@kg.ac.rs

Faculty of Economics, Universtity of Kragujevac; jokasavic92@gmail.com 


\section{Introduction}

Along with the development of corporations, there is a separation of ownership from control due to delegation of management rights from owners to managers. When managers make decisions in the interests of the owners, the latter will benefit. Otherwise, when there is opportunistic behavior of managers, a conflict of interest between owners (principals) and managers (agents) arises. ${ }^{1}$ In order to resolve this conflict, different corporate governance mechanisms are applied, which are classified in the literature in two basic groups of mechanisms: internal mechanisms, which refer to the ownership structure and the board of directors, and the corporate control market and institutional framework as external mechanisms. ${ }^{2}$ Due to the insufficiently developed corporate control market, the internal mechanisms of corporate governance are particularly important for transition countries. According to the agency theory, the basic role of the board as an internal mechanism is to monitor and control the managers in order to protect the interests of the owners. Thus, it is one of the basic research issues on which the board effectiveness depends.

Although there is a body of empirical research, partial research on the board effectiveness does not generally include the institutional context in which the research is conducted. Starting from the need to reduce this gap, the paper focuses on the board as an internal mechanism that depends on the institutional framework. The theoretical basis of research is institutional theory as one of the contemporary theories of corporate governance. From the perspective of institutional theory, companies are seen as social entities integrated into an institutional framework that identifies formal and informal standards on the organizational structure, including board structure ${ }^{3}$ that reflects the national culture in which the organization operates. ${ }^{4}$

Culture is considered to be an important factor within the informal institutional framework and for that reason it can be assumed that the board structure is related to the dimensions of national culture. The corporate governance system analyzed through the board structure varies from country to country, from the two-tier board model in the Continental-European

Nikolić Jelena,Babić Verica (2016):"Zaštita interesa investitora kao faktor unapređenja konkurentnosti privrede", Zbornik radova Unapređenje konkurentnosti privrede Republike Srbije, 206.

2 Babić Verica, Nikolić Jelena, Stanisavljević Milena (2016): "Corporate governance mechanisms effectiveness: the case of transition countries", Facta Universitatis, 13/2, 4.

3 Li Jitao, Harrison J. Richard (2008a):"National Culture and the Composition and Leadership Structure of Boards of Directors", Corporate Governance: An International Review, 16 /5, 377.

4 HumphriesA.Sarah, Whelan Catherine (2017):"National Culture and Corporate Governance Codes", Corporate Governance: The International Journal of Business in Society, 17/1, 152. 
countries to the one-tier board model in the Anglo-Saxon countries. Mark Roe (1994) considers these variations as a result of differences in national culture 5 . Nevertheless, in literature emphasis is placed on the analysis of the impact of the legal and political framework on the ownership and control, while little attention is paid to the analysis of the influence of national culture and its dimensions on the board structure. Therefore, because research in transitional economies related to this problem field is limited, and in Serbia in particular, where to the best of the authors' knowledge no such research has yet been conducted, this study fills the gap in the literature.

Starting from the above mentioned, a pilot study was conducted to examine the impact of the dimensions of national culture on the board structure in Serbia and Montenegro. In fact, the aim of the research is to examine whether the board structure is the same in the countries that have the same dimensions of national culture. The research starts from the widely accepted cultural framework developed by Geert Hofstede, in which he identified four dimensions of culture: uncertainty avoidance, individualism/collectivism, power distance and masculinity/femininity. ${ }^{6}$ The obtained results concerning the link between the national culture and the board structure are the basis for carrying out comprehensive research in order to draw conclusions about the impact of dimensions of national culture on the board structure. In line with the purpose of the research, the work consists of the following parts: in the first part of the paper, an overview of previous research is carried out which examines the impact of the dimensions of national culture on the board structure; the second part describes the methodology used in the research; based on the secondary data and by using descriptive statistics and the $\mathrm{T}$ test, research results are presented in the third part of the paper; the final part of the paper presents concluding remarks, points to the research limitations and gives directions for future research.

\section{Literature review}

Scott states that every organization, as a social system, operates as part of an institutional environment that determines social reality. ${ }^{7}$ Institutional environment viewed as a set of formal and informal institutions is variable and consists of many different factors that have a significant impact on the characteristics of the organization. A formal institutional framework, through the definition of norms related to the board structure, shapes a corporate governance $5 \quad$ According to: Lubetsky H. Michael (2008):"Cultural difference and corporate governance", 17 Transnat'l L. \& Contemp. Probs,187/2008, 189.

$6 \quad$ Hofstede Geert (1983a):"National cultures in four dimensions: A research-based theory of cultural differences among nations", International Studies of Management \& Organization, 13/1-2, 46 .

$7 \quad$ Scott W. Richard (1987):"The adolescence of institutional theory", Administrative science quarterly, 32/4, 507.

Vol. 16, № 1, 2019: 123-138 
system. An informal institutional framework also plays a significant role through cultural elements such as symbols, cognitive systems and normative beliefs. Based on the above, the corporate governance system is influenced not only by formal institutions, but also by national culture, as an informal institutional framework. ${ }^{8}$

The notion of culture has been widely studied in the literature and defined in different ways. The generally accepted definition of culture was given by Geert Hofstede, who defines culture as 'a collective programming of the mind that distinguishes members of one group of people from others." ${ }^{9}$ Different frameworks have been developed for the study and understanding of national culture, but it is certainly the most widely used framework defined by Hofstede, which includes four dimensions: uncertainty avoidance, individualism/ collectivism, power distance and masculinity/femininity. ${ }^{10}$ To this model Hofstede added two more dimensions - short-term/long-term orientation and indulgence/restraint. ${ }^{11}$ In this research, the first four dimensions are analyzed.

Uncertainty avoidance refers to the extent to which a society feels fearful about uncertain situations and in which it tries to avoid such situations by setting formal rules without tolerating different ideas or behaviors and believing in absolute truth. ${ }^{12}$ According to this dimension, societies can be characterized as those with a low degree of uncertainty avoidance, in which individuals prefer to take risks, tolerate differences, do not feel upset about the existence of uncertainty and have a natural tendency to feel safe, whereas those with a high degree of uncertainty avoidance in which individuals try to win the future, feel anxiety and nervousness, as well as trying to create security and avoid risk. ${ }^{13}$

The power distance shows the degree to which society accepts the fact that power in institutions and organizations is unequally distributed. ${ }^{14,15}$ Societies can have a high power distance when they allow inequalities in society to grow

$8 \quad$ Li Jitao, Harrison J. Richard (2008b):"Corporate governance and national culture: a multicountry study", Corporate Governance: The international journal of business in society, 8/5, 612.

$9 \quad$ Hofstede Geert (1994):"The business of international business is culture", International business review, $3 / 1,1$.

10 Hofstede Geert (1983a), 46.

11 Hofstede Geert (2011):"Dimensionalizing cultures: The Hofstede model in context", Online readings in psychology and culture, $2 / 1,8$.

12 Hofstede Geert (1980):"Motivation, leadership, and organization: do American theories apply abroad?", Organizational dynamics, 9/1, 45.

13 Hofstede Geert (1983b):"The cultural relativity of organizational practices and theories", Journal of international business studies, 14/2, 81-83.

14 Hofstede Geert (1980), 45.

15 Mintz M. Steven (2005):"Corporate governance in an international context: Legal systems, financing patterns and cultural variables", Corporate governance: an international review, $13 / 5,587$. 
in terms of power and wealth, and when they tend to reduce these differences as much as possible, they are characterized by a low power distance. Individualism/ collectivism is a dimension that explains the relationship between individuals and groups and refers to the degree of integration of individuals into groups. ${ }^{16}$ In fact, differentist cultures are distinguished in which individuals strive for autonomy and independence, and collectivist cultures in which individuals maintain strong ties to their primary groups. Masculinity/femininity refers to the dimension of culture that shows the distribution of dominant values in a society among the sexes. ${ }^{17}{ }^{18}$ In societies where there is a dominance of masculinity, the emphasis is on the existence of gender differences, ambition, the acquisition of wealth, aggressiveness, while societies with dominant femininity emphasize the importance of establishing good relationships, caring for harmony and quality of life, modesty.

A particularly important aspect in research dealing with the board effectiveness is to examine the impact of different dimensions of national culture on the board structure. The board role is to ensure that managers act in the interests of owners and key stakeholders, and their key responisbillity is to provide strategic orientation of the corporation and supervise and control the management. ${ }^{19}$ Numerous studies of corporate governance have studied the role and structure of the board of directors from different perspectives, resulting in the development of a number of theories concerning corporate governance. ${ }^{20}$ The board structure is analyzed through the following key characteristics: board composition, leadership structure and board size. Board composition shows the relationship between the number of non-executive, independent directors, and the number of executive directors. Leadership structure is defined as the duality position of the board chairman and CEO (chief executive officer). ${ }^{21}$

The above structural characteristics of the board vary depending on the corporate governance model. A unitary board or one-tier board is the form of board structure common in the UK and the USA. This means that the functions

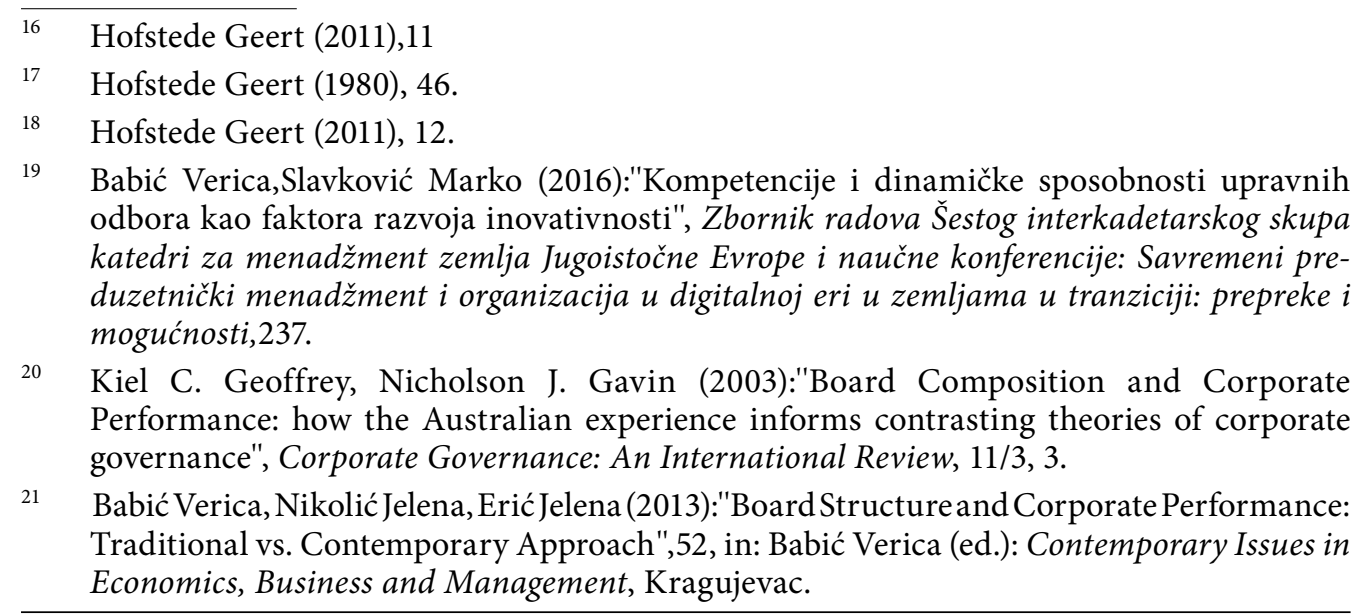


of management and control are unified and assigned to one single board, which is composed of both executive and non-executive, independent members. The board is elected by the shareholders, and board members play a key role in corporate governance. Although the board size is not legally limited, according to the Corporate Governance Code, large companies should have at least half of the non-executive, independent directors, while small companies must have at least two non-executive directors. ${ }^{22}$ The Anglo-Saxon unitary board model is characterized by a dual leadership structure, which implies the duality position of the board chairman and CEO.

Unlike the Anglo-Saxon board model, a dual or two-tier board implies the separation of management and control functions, which is typical of the Continental Europe. ${ }^{23}$ The two-tier or dual board consists of two separate boards - the supervisory board and the management board. The main characteristic is that members of the management board are not allowed to be members of the supervisory board at the same time. ${ }^{24}$ The supervisory board is composed of external, non-executive members. It has the task of monitoring the managers and taking care of the long-term development of the company. Its responsibilities include the appointment and dismissal of the members of the management board, advising, supervising and controlling the management board, as well as the ratification of strategic decisions. The management board consists of executive members, which has no right to become involved in the work of the supervisory board. The members of the management board are appointed by the supervisory board. The management board is responsible for conducting business and representing companies. In line with above mentioned, the roles and responsibilities of supervisory and management boards are separated - the management board manages the company, and the supervisory board oversees the direction of the business. With this model, the duality leadership structure is not allowed, which means that the general manager can not be the chairman of the board at the same time. ${ }^{25}$

Although there are differences in the board models, the board composition, the board size and the leadership structure are the basic structural characteristics which determine their effectiveness. Considering the board importance, numerous researches have been studying the board characteristics depending on the dimensions of the national culture. Many of them point to the importance of the independence of directors, gender, education, ethnic origin. The heterogeneity of the board can be viewed as a consequence of the influence of Hofstede's dimensions of national culture. Cimerova et al. found that differences

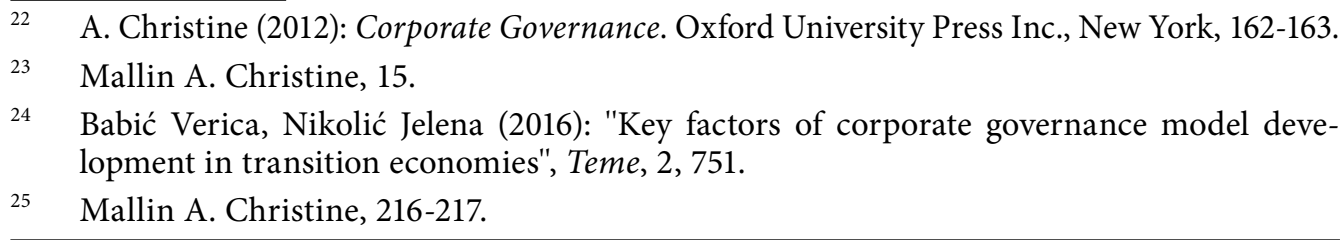


in individualism and collectivism, as well as the dominance of masculinity, had a negative impact on the board effectiveness. ${ }^{26}$ Oostveen et al. have proven that power distance, masculinity and uncertainty avoidance, as a dimension of national culture, affect gender representation on board.$^{27}$ Therefore, genderbased behavioral differences between males and females may lead to differences in board effectiveness.

In a survey on a sample of 399 multinational companies from 15 countries of a different cultural environment, Li and Harrison have confirmed that all dimensions of national culture have a significant impact on the board composition and leadership structure. ${ }^{28}$ The research is based on the results of earlier conducted studies, such as Hill, which emphasize that group performances are quantitatively and qualitatively superior to the performance of individuals. ${ }^{29}$ In favor of this we can emphasize that different individuals have different learning capacities and cognitive influence on other team members, which makes the groups more capable of solving complex problems. On the basis of the obtained results, the authors assume that a larger number of external members with different knowledge and experience will contribute to the board effectiveness. Also, starting from research conducted by Boyd ${ }^{30}, \mathrm{Li}$ and Harrison point to significant positive influence of the CEO duality on performance. They concluded that uncertainty avoidance and individualism positively influence the board structure with a larger number of external members and CEO duality, as well. Therefore, they state that masculinity and high power distance are associated with a smaller number of external members, but they also affect the CEO duality.

The same authors investigate the influence of dimensions of national culture on the board size and leadership structure on the same sample as in the previous survey. The results of this study are consistent with the previous ones in terms of the impact of high power distance, individualism and masculinity on CEO duality, but differ regarding uncertainty avoidance impact. ${ }^{31}$ They show that this dimension positively affects the separation of chairman and CEO roles. Concerning the board size, research shows that a high degree of individualism

26 Cimerova Helena, Dodd Olga,Frijns Bart (2014):"The impact of cultural diversity in corporate boards on firm performance", http://www.nzfc.ac.nz/archives/2015/papers/programme/132.pdf (16.05.2017).

27 Oostveen van Boris, Dam Lammertjan,Niels Hermes (2014):"Women on Boards of Directors and Firm Performance: Does Culture Matter?", EFMA23rd Annual Conference, Tor Vergata - School of Economics, University of Rome,22-23.

28 Li Jitao, Harrison J. Richard (2008a), 381.

$29 \quad$ Hill W. Gayle (1982):"Group versus individual performance: Are N+1 heads better than one?", Psychological bulletin, 91/3, 533.

$30 \quad$ BoydK.Brian (1995):"CEO duality and firm performance: A contingency model", Strategic Management Journal, 16/4, 301-312.

31 Li Jitao, Harrison J. Richard (2008b), 618. 
encourages small boards with fewer members, while the dominance of masculinity influences bigger boards. However, their starting assumptions that the power distance is linked to smaller boards have not been proven.

Humphries and Whelan point to the significant relationship between Hofstede's dimensions of culture and leadership structure, the board composition by gender, the board independence, and the frequency of board meetings. ${ }^{32}$ Based on secondary data on corporate governance codes in 55 countries, these authors grouped countries into following groups: the first group, formed by the countries in which corporate governance codes require the boards with a balanced gender structure and diversification, a greater number of independent members, a separate CEO and chairman position, and a regular number of board meetings during the year; and the second group, consisting of the countries that do not regulate the board structure or the frequency of meetings, whose boards have sufficient but not the majority of independent members, and where the separation of the CEO and the board chairman is not required. For both groups, a score was determined for each dimension of national culture, and their impact on corporate governance variables was observed. The results showed that high power distance, masculinity and uncertainty avoidance affect the existence of codes related to board structure, and that all four dimensions influence the requirements for the independent boards. As far as the leadership structure is concerned, only power distance dimension stimulates the duality of positions.

Starting from the results of the above research, and having in mind that corporate governance in transition countries is insufficiently explored, the paper starts from the dimensions of national culture in Serbia and Montenegro characterized by collectivism, high power distance, femininity and uncertainty avoidance ${ }^{33} 343536$ as determinants that shape the board structure. Drawing on the literature review, the starting point is that countries that have the same dimension of national culture also have boards with similar structural characteristics. In accordance with the above, and starting from the fact that the national culture in Serbia and Montenegro is characterized by similar dimensions of national culture, the following research hypotheses have been tested:

H1: There are no statistically significant differences between the board composition in Serbia and Montenegro.

32 Humphries A. Sarah, Whelan Catherine, 161.

33 Janićijević Nebojša (2003):"Uticaj nacionalne kulture na organizacionu strukturu preduzeća u Srbiji", Ekonomski anali, 44/156, 54.

34 Obradović Saša, Rakić Biljana, Šapić Srđan (2011):"Kulturološke razlike kao faktor ekonomskog uspeha", Ekonomske teme, 4, 621-622.

35 Krivokapić Nataša,Ćeranić Goran (2014):"Dominant Value Patterns in the Montenegrin Society", Mediterranean Journal of Social Sciences, 5/13, 205.

36 Jovanović Violeta, Paunković Jane, Stevanović Marija (2017): "Organizational learning for sustainable development - correlation with the national culture dimenssions framework", Megatrend Review, 14/3,7. 
$\mathrm{H} 2$ : There are no statistically significant differences between the board size in Serbia and Montenegro.

\section{Research Methodology}

This pilot survey is based on secondary data on the board structure collected from 30 companies in Serbia listed on the Belgrade Stock Exchange and 30 companies in Montenegro listed on the Montenegro Stock Exchange. Thus, the whole sample includes a total of 60 companies, which fulfilled the requirement regarding the minimum size of the sample for conducting the statistical analysis. In order to achieve the sample diversity and ensure comparability of data collected, the sample included companies in various industries. It is also important to note that, in order to harmonize the sample, only companies with unitary board are studied, given the fact that there can be unitary and dual boards in companies in Serbia, ${ }^{37}$ but that in companies in Montenegro the governance bodies can only be the board of directors and the executive director, ${ }^{38}$ which means that there are no supervisory boards and therefore neither a dual board model.

In order to empirically test the hypotheses, descriptive statistical analysis and the T test for two independent samples were applied (SPSS 20.0). According to the sample, the number of non-executive members is generally higher than the number of executive members ( $86.67 \%$ of the sample) in boards in Serbia. The boards have most often two non-executive members ( $70 \%$ of the sample), followed by four non-executive members ( $16.7 \%$ of the sample), while a small percentage of the sample is the boards which have three, five and ten nonexecutive members. Therefore, based on previously explained results, it can be concluded that the boards make a greater number of non-executive, external members.

Another examined characteristic is the board size. When it comes to the number of board members, it has about three members in the majority of companies in Serbia (60\% of the sample), followed by boards with five members ( $20 \%$ of the sample), then with seven members ( $10 \%$ of the sample), and finally there are companies with six members or even eleven members. In companies in Montenegro, it can be concluded that there are a large number of external board members in relation to internal ones. Most often there are four $(26.7 \%$ of the sample), five (33.3\% of the sample) and seven external members (16.7\% of the sample). Therefore, based on these results, it can be concluded that the boards

Zakon o privrednim društvima Republike Srbije, Službeni glasnik RS, br. 36/2011, 99/2011, 83/2014 - dr. zakon i 5/2015, čl. 326.

38 Zakon o privrednim društvima Crne Gore, Službeni list Republike Crne Gore, br. 006/02 od 08.02.2002, Službeni list Crne Gore", br. 017/07 od 31.12.2007, 080/08 od 26.12.2008, 040/10 od 22.07.2010, 036/11 od 27.07.2011, 040/11 od 08.08.2011, čl. 34 . 
in Montenegro consist of a greater number of non-executive, external members. Regarding the board size, research results show that in most companies, the boards consist of five members (53.3\% of the sample), three members ( $23.3 \%$ of the sample) and seven members (23.3\% of the sample).

\section{Results and discussion}

In Table 1, results of descriptive statistical analysis for analyzed companies in Serbia and Montenegro are given. In this table, number 1 signifies Serbia, while number 2 denotes Montenegro. According to the obtained mean values, the average number of external board members in Serbia is 2.76 and in Montenegro is 4.63 . Regarding the board size, the values show that the average number of board members in Serbia is 4.36 and 5 in Montenegro.

Table 1. Descriptive statistics for composition and size of board of directors

\begin{tabular}{|c|c|c|c|c|c|}
\hline $\begin{array}{c}\text { Board } \\
\text { characteristics }\end{array}$ & Country & $\mathbf{N}$ & Mean & $\begin{array}{c}\text { Std. } \\
\text { Deviation }\end{array}$ & $\begin{array}{c}\text { Std. Error } \\
\text { Mean }\end{array}$ \\
\hline \multirow{2}{*}{ Non-executive } & 1 & 30 & 2,7667 & 1,63335 &, 29821 \\
\cline { 2 - 6 } & 2 & 30 & 4,6333 & 1,40156 &, 25589 \\
\hline \multirow{2}{*}{ Size } & 1 & 30 & 4,3667 & 2,07586 &, 37900 \\
\cline { 2 - 6 } & 2 & 30 & 5,0000 & 1,38962 &, 25371 \\
\hline
\end{tabular}

Source: author's survey data

Following, T-test for two independent samples was carried out showing whether there are statistically significant differences between the board composition and the board size in Serbia and in Montenegro. The results of the T-test are shown in the Table 2.

Table 2. $T$ test results

\begin{tabular}{|c|c|c|c|c|c|c|}
\hline $\begin{array}{c}\text { Board } \\
\text { characteristics }\end{array}$ & F & Sig. & $\mathbf{t}$ & $\begin{array}{c}\text { Sig. } \\
\text { (2-tailed) }\end{array}$ & $\begin{array}{c}\text { Mean } \\
\text { Difference }\end{array}$ & $\begin{array}{c}\text { Std. Error } \\
\text { Difference }\end{array}$ \\
\hline Non-executive & 0,037 &, 849 & $-4,750$ &, 000 & $-1,86667$ &, 39295 \\
\hline Size & 5,860 &, 019 & $-1,389$ &, 171 &,- 63333 &, 45608 \\
\hline
\end{tabular}

Source: author's survey data

According to the results obtained, we can conclude that there is a statistically significant difference in the board composition, because $\mathrm{p}<0,01$. In fact, the mean values for the board composition significantly differ $(\mathrm{M}=2.76$ and $\mathrm{M}=4.63)$. The results show that the boards in Serbia and Montenegro differ regarding their 
composition. Accordingly, it can be concluded that the hypothesis $\mathrm{H}_{1}$ has not been confirmed. The results are incompatible with the theoretical assumptions, which makes them important for determining the cause of the obesrved deviation.

The results demonstrate that there is no statistically significant difference in the board size. In fact, the mean values indicate how the boards differ in regard to the observed characteristics. Based on these values, it can be seen that the boards do not differ significantly when it comes to their size $(\mathrm{M}=4.36$ and $\mathrm{M}=5.00)$. It means that the hypothesis $\mathrm{H}_{2}$ is confirmed, which is in line with the theoretical assumption that the size as the board structural dimension should be similar to the size of those companies that operate in the same or similar national culture.

\section{Conclusion}

The study of the national culture, especially research addressing the link between the national culture and corporate governance, has increased along with the globalization. This trend emerged as a response to the need to examine the correlation between corporate governance models and the institutional framework. In accordance with the fact that corporate governance models vary depending on the corporate control mechanisms, one of the relevant issues is the connection between national culture and the corporate control mechanisms. A central theme in economic research is to examine the influence of national culture on the board structure, as an important internal mechanism of corporate control. However, the empirical results in this research area are still modest, which is why the conducted research has a significant implications for institutional reform in transition economies.

In this pilot research adrressing the national culture as a determinant of the board structure, we started from the following key dimensions of the national culture in Serbia and Montenegro: a high degree of uncertainty avoidance, a high power distance, collectivism and the dominance of masculinity. In accordance with the similarity of national culture in Serbia and Montenegro, it is assumed that the research results should confirm the similar board structure. However, the results obtained from the comparative analysis based on the T-test show that there is no statistically significant difference in the board size, but that the board composition differs. The observed difference identified using the T-test shows that, compared to board composition in Serbia, boards in Montenegro have a larger number of external members than internal ones. Given that there are no similar studies carried out in this area, it is of great importance that the analysis be deepened in order to examine the causes of the above deviation. The findings are significant because they indicate that the mechanisms of corporate control should be analyzed depending on the institutional framework. 
In fact, these results open a new research question why there are deviations from the presumed interdependence of national culture and board structure. The above points to the need for further research on a larger sample that will include more countries with a similar national culture dimensions in order to make general conclusions. In fact, future research should deal with the study of the impact of Hofstede's cultural dimensions on the board structure. This analysis could help to detect the cause of the observed deviation. In this way, it would be possible to draw conclusions about the specific impact of each of the Hofstede's cultural dimensions. Although the four dimensions are used in research on the impact of national culture, it is also important to include the two dimensions added and to examine whether there are differences in these dimensions.

\section{Literature}

- Babić Verica, Nikolić Jelena, Erić Jelena (2013): 'Board Structure and Corporate Performance: Traditional vs. Contemporary Approach", 52, in: Babić Verica (ed.): Contemporary Issues in Economics, Business and Management, 49-63, Kragujevac.

- Nikolić Jelena, Babić Verica (2016): ,'Zaštita interesa investitora kao faktor unapređenja konkurentnosti privrede", Zbornik radova Unapređenje konkurentnosti privrede Republike Srbije, 205-216, Ekonomski fakultet, Kragujevac.

- Babić Verica, Nikolić Jelena (2016): ,'Key factors of corporate governance model development in transition economies", Teme, 2, 747-761.

- Babić Verica, Nikolić Jelena, Stanisavljević Milena (2016): ,'Corporate governance mechanisms effectiveness: the case of transition countries", Facta Universitatis, 13/2, 161-175.

- Babić Verica, Slavković Marko (2016): 'Kompetencije i dinamičke sposobnosti upravnih odbora kao faktora razvoja inovativnosti", Zbornik radova Šestog interkadetarskog skupa katedri za menadžment zemlja Jugoistočne Evrope $i$ naučne konferencije: Savremeni preduzetnički menadžment i organizacija $u$ digitalnoj eri u zemljama u tranziciji: prepreke i mogućnosti, 235-250, Ekonomski fakultet, Banja Luka.

- Boyd K. Brian (1995): ,'CEO duality and firm performance: A contingency model", Strategic Management Journal, 16/4, 301-312.

- Cimerova Helena, Dodd Olga, Frijns Bart (2014): ,'The impact of cultural diversity in corporate boards on firm performance", http://www.nzfc.ac.nz/ archives/2015/papers/programme/132.pdf (16.05.2017).

- Hill W. Gayle (1982): ,'Group versus individual performance: Are N+ 1 heads better than one?", Psychological bulletin, 91/3, 517-539. 
- Hofstede Geert (1980): ,'Motivation, leadership, and organization: do American theories apply abroad?", Organizational dynamics, 9/1, 42-63.

- Hofstede Geert (1983a): ',National cultures in four dimensions: A researchbased theory of cultural differences among nations", International Studies of Management \& Organization, 13/1-2, 46-74.

- Hofstede Geert (1983b): ,'The cultural relativity of organizational practices and theories", Journal of international business studies, 14/2, 75-89.

- Hofstede Geert (1994): ,'The business of international business is culture", International business review, 3/1, 1-14.

- Hofstede Geert (2011): ,'Dimensionalizing cultures: The Hofstede model in context", Online readings in psychology and culture, 2/1, 1-26.

- Humphries A. Sarah, Whelan Catherine (2017): ,'National Culture and Corporate Governance Codes", Corporate Governance: The International Journal of Business in Society, 17/1, 152-163.

- Janićijević Nebojša (2003): ,'Uticaj nacionalne kulture na organizacionu strukturu preduzeća u Srbiji", Ekonomski anali, 44/156, 45-66.

- Jovanović Violeta, Paunković Jane, Stevanović Marija (2017): ,'Organizational learning for sustainable development - correlation with the national culture dimenssions framework", Megatrend Review, 14/3, 1-20.

- Kiel C. Geoffrey, Nicholson J. Gavin (2003): ,'Board Composition and Corporate Performance: how the Australian experience informs contrasting theories of corporate governance", Corporate Governance: An International Review, 11/3, 189-205.

- Krivokapić Nataša, Ćeranić Goran (2014): ,'Dominant Value Patterns in the Montenegrin Society", Mediterranean Journal of Social Sciences, 5/13, 205209.

- Li Jitao, Harrison J. Richard (2008a): ,'National Culture and the Composition and Leadership Structure of Boards of Directors", Corporate Governance: An International Review, 16 /5, 375-385.

- Li Jitao, Harrison J. Richard (2008b): ,'Corporate governance and national culture: a multi-country study", Corporate Governance: The international journal of business in society, 8/5, 607-621.

- Lubetsky H. Michael (2008): ,'Cultural difference and corporate governance", 17 Transnat'l L. \& Contemp. Probs, 187/2008, 190-211.

- Mallin A. Christine (2012): Corporate Governance. Oxford University Press Inc., New York

- Mintz M. Steven (2005): ,'Corporate governance in an international context: Legal systems, financing patterns and cultural variables", Corporate governance: an international review, 13/5, 582-597.

- Obradović Saša, Rakić Biljana, Šapić Srđan (2011): ,'Kulturološke razlike kao faktor ekonomskog uspeha", Ekonomske teme, 4, 619-632. 
- Oostveen van Boris, Dam Lammertjan, Niels Hermes (2014): ,'Women on Boards of Directors and Firm Performance: Does Culture Matter?", EFMA $23^{\text {rd }}$ Annual Conference, Tor Vergata - School of Economics, University of Rome, 1-39.

- Scott W. Richard (1987): ,'The adolescence of institutional theory", Administrative science quarterly, 32/4, 493-511.

- Zakon o privrednim društvima Crne Gore, Službeni list Republike Crne Gore, br. 006/02 od 08.02.2002, Službeni list Crne Gore”, br. 017/07 od 31.12.2007, 080/08 od 26.12.2008, 040/10 od 22.07.2010, 036/11 od 27.07.2011,040/11 od 08.08.2011.

- Zakon o privrednim društvima Republike Srbije, Službeni glasnik RS, br. 36/2011, 99/2011, 83/2014 - dr. zakon i 5/2015. 


\section{VEZA IZMEĐU STRUKTURE UPRAVNOG ODBORA I NACIONALNE KULTURE: KOMPARATIVNA ANALIZA}

Kao posledica razdvajanja vlasništva od kontrole i uspostavljanja odnosa između vlasnika kao principala i menadžera kao agenata, dolazi do pojave tzv. agencijskog problema. Za ublažavanje agencijskog problema u tranzicionim ekonomijama primenjuju se interni mehanizmi korporativnog upravljanja. Kultura se smatra jednim od značajnih faktora $u$ okviru neformalnog institucionalnog okvira koji se često dovodi u vezu sa efektivnošću mehanizama korporativnog upravljanja. Polazeći od stava da je upravni odbor važan interni mehanizam, u radu se istražuje nacionalna kultura kao determinanta strukture upravnog odbora. Istraživanje je zasnovano na široko prihvaćenom kulturalnom okviru koji je razvio Gert Hofstede. Cilj istraživanja je da se dođe do relevantnih naučnih saznanja o tome da li se struktura upravnih odbora, posmatrana kroz kompoziciju $i$ veličinu, razlikuje u zemljama koje odlikuju slične dimenzije nacionalne kulture. Istraživanje je sprovedeno na uzorku od 60 preduzeća u Srbiji i Crnoj Gori. Koristeći T test, rezultati istraživanja su pokazali da se kompozicija upravnih odbora u analiziranim zemljama razlikuje, dok je prosečna veličina ista. Rezultati sprovedenog pilot istraživanja ublažavaju istraživački gep koji postoji u domaćoj literaturi i predstavljaju osnovu za buduća istraživanja u ovoj oblasti.

Ključne reči: korporativno upravljanje, mehanizmi korporativnog upravljanja, nacionalna kultura, struktura upravnog odbora 